\title{
Imagery in Dover Beach Poem: Psychoanalytic Perspective
}

\author{
Euis Meinawati ${ }^{1}$, Lisnawati $^{2}$ \\ ${ }^{12}$ English Department/ Universitas Bina Sarana Informatika Jakarta \\ ${ }^{1}$ e-mail: euis.eum@bsi.ac.id \\ 2e-mail: liezna_1408@yahoo.com

\begin{tabular}{ccc}
\hline Diterima & Direvisi & Disetujui \\
$08-01-2020$ & $09-02-2020$ & $28-02-2020$ \\
\hline
\end{tabular}

\begin{abstract}
Poetry/poem as one of a literary works is definitely an interesting subject to be analyzed. In a poem there are some elements that are valuable as an analysis source. One of them is Imagery. Imagery is used in a poem to help the readers in understanding and comprehending the whole poem because through imagery the readers can imagine every word, they are reading in the poem so they can see, feel, touch, hear, taste and smell the thing that is described by the speaker/poet. Literary work also can be analyzed by its extrinsic elements which is literary criticism or multi disciplines. One of phenomenal literary criticism is psychoanalytic perspective. Through psychoanalytic perspective the work of literature reveals the psychoanalytic aspect of the depth true feeling of the author. The purpose of this analysis is to know what kinds of imagery contained in Dover Beach poem written by Matthew Arnold. The method of this analysis is using descriptive and qualitative methods by reading and underlining the line and stanza contains imagery and every line and stanza reveals the psychoanalytic aspect. The result of this analysis is the writer finds out there are some imagery contained in Dover Beach poem. Dover Beach poem contains Visual Imagery, Olfactory Imagery, Auditory Imagery, Kinesthetic Imagery, and Organic Imagery. In Dover Beach poem are found some of psychoanalytic aspects such as unconscious and the id, ego, and superego in Dover Beach poem.
\end{abstract}

\section{Key Word: Imagery, Psychoanalytic Perspective, Matthew Arnold's Poems}

\begin{abstract}
Abstrak - Pencitraan digunakan dalam sebuah puisi untuk membantu pendengar memahami secara keseluruhan isi puisi karena melalui pencitraan, pendengar dapat membayangkan setiap kata, mereka membaca puisi sehingga mereka dapat melihat, merasakan, menyentuh, mendengar, dan mencium sesuatu hal yang dijelaskan oleh penyair. Karya sastra juga dapat dianalisis melalui elemen ekstrinsiknya yaitu kritik sastra atau multi disiplin ilmu. Salah satu kritik sastra yang fenomenal adalah perspektif psikoanalitik. Melalui perspektif psikoanalisis, karya sastra mengungkapkan aspek psikoanalitik dari perasaan sejati penulis. Tujuan dari analisis ini adalah untuk mengetahui jenis citra apa yang terkandung dalam puisi berjudul Dover Beach yang ditulis oleh Matthew Arnold. Metode analisis menggunakan metode deskriptif kualitatif melalui tahapan membaca dan menggarisbawahi garis dan bait yang berisi citra dan setiap baris serta bait mengungkapkan aspek psikoanalitik. Hasil analisis menunjukkan bahwa ada beberapa pencitraan yang terkandung dalam puisi Dover Beach. Puisi Dover Beach berisi Pencitraan Visual, Pencitraan Penciuman, Pencitraan Auditori, Pencitraan Kinestetik, dan Pencitraan Organik. Pada puisi Dover Beach ditemukan beberapa aspek psikoanalisis seperti ketidaksadaran dan id, ego, dan superego dalam puisi Dover Beach.
\end{abstract}

Kata Kunci: Pencitraan, Perspektif Psikoanalitik, Puisi Matius Arnold

\section{INTRODUCTION}

Reading or watching literary works is always interesting. Some people are being involved to some literary works in their daily life. They read short story or novel, watch drama performance in theatre, or watch movies in cinema. The objects in those activities are part of literature; short story, novel, drama, and movie/film. For most people their intention of using literature is for getting some pleasure or fun or relaxing and refreshing their mind after the hectic day in work. DiYanni (2004:1) argues "many people read literature for pleasure.
Many others read literary works mainly to satisfy academic requirements. Duty and pleasure, however, are not mutually exclusive." There is difference purpose in using literature. In school literature is being important major that must be mastered by students. It is as a requirement for improving student's writing ability and increasing their understanding of what they read. Whether literature is used for entertainment or requirement, it is still same in such way that literature is as a big part in human life and as a need for different purpose. 
However, there is a literary work that is not popular anymore today. As the age of electricity gadgets develop fast nowadays, poetry has been left by most people. As Dietsch (2003:450) argues "now there just does not seem to be time to read poetry and ponder tendrils of meaning." Poetry/poem is one of literary works which is not as interesting as the other literary works for most people. People are just too busy to spend more time and stare at the combination of connotative words in a poem. Another reason poem is not being fond is because poem is hard to be absorbed. Poetry requires more effort and time in reading. It has to be read slowly, intensely, carefully and attentively to interpret its real meaning. The difficulties of understanding poetry/poem become the excuse for some people not to involve poetry/poem for entertainment. Stanford (2006:59) states "originally, poetry was entirely an oral from passed from a speaker to a listener (who often then became a speaker for new listeners)." It means poem is originally oral form which is sent by a speaker directly to a listener, the listener then become a speaker for new listeners.

The fact that reading a poem is not as easy as reading prose is because prose uses denotative words and states clearly what the story is all about. On the other hand, poetry uses connotative words and intents to hide the real meaning or message of the story to be revealed by the readers. A Poem uses specific devices such as diction, syntax, imagery, figurative language, rhyme, assonance, alliteration, rhythm, meter and structure as its basic elements. Interpreting a poem needs a depth understanding of its basic elements or intrinsic elements in order to express the appropriate combination of meaning and emotion.

One of the intrinsic elements that is interesting to be analyzed in a poem is imagery. The use of imagery gives imagination to the readers of what the poem is described, because images are the pictures that poets create with their words. A poem needs to be discussed and analyzed, in order to understand the message and the depth of true meaning contained on it. By using deep analysis and right theory the message in the poem can be unveiled. The reader can explore every stanza, line, and word in poem, and analyze its basic or intrinsic elements such as imagery. Pharr and Buscemi (2005:541) have opinion about imagery in their statement "image is a description meant to evoke a mental picture for the reader." The picture or image that readers see on their mind is the mental picture which is the picture or image they do not really see or feel it. Like as visual imagery, Perrine \& ARP (1992) in her statement "Visual imagery represents something seen in the mind's eye, or it can be explained as something stimulated in the sense of sight" This imagery is commonly the most images that appear in a poem.
Literary work does not only contain its intrinsic elements, but also its extrinsic elements such as the society, culture, or situation around the writer which influence the works. Based on that fact, critical perspectives are used to analyze and interpret literary works in order to gather more information. One of the critical perspectives is psychoanalytic perspective. Psychoanalytic perspective is used to understand literary texts better, which are about human behaviours. In psychoanalytic perspective literary works are assumed conveying the writer's deep thought and repressed emotion. Eagleton (2008:131) argues that psychoanalytic is "a crisis of human relationships, and of the human personality, as well as a social convulsion." Psychoanalytic is the analysis of the crisis of human relationship between their personality, other people, society, and even environment. Barry (2002:69) "psychoanalytic criticism is a form of literary criticism which uses some of the techniques of psychoanalysis in the interpretation of literature." According to Barry psychoanalytic criticism is the criticism of literary work using psychology analysis in approaching and understanding the works. The writer's belief, value, and perception about the world and life will be reflected in their works consciously or unconsciously. According to Freud the unconscious mind is a reservoir of feelings, thoughts, urges, and memories that outside of people conscious awareness. Most of the contents of the unconscious are unacceptable or unpleasant, such as feelings of pain, anxiety, or conflict (Barry, 2002).

There are many great poems created by many great poets. Different poet will give or suggest different opinion and message contained in their poems. One of the most influential poets in Victorian era is Matthew Arnold (1822-1888). He is a unique writer who shares his values, attitudes, and feeling about the society, education, and religious issues. One of the most famous works of Matthew Arnold is Dover Beach poem.

Realizing that poetry is a subject which is difficult but at the same time is also interesting to be discussed the writer is encouraged to analyze it based on the aspects, the writer described above, imagery and psychoanalytic perspective. In this paper, the writer intends to analyze the technique of imagery development in Matthew Arnold's poems which is Dover Beach. This poem contains a lot of imageries. The analyzing of poems uses psychoanalytic perspective because the poem has psychoanalytic aspect which is interesting and challenging to be discussed. The purpose of this study is to explore the imageries of Dover Beach poems using psychoanalytic perspective. 


\section{REASEARCH METHODOLOGY}

This paper uses descriptive qualitative method. According to Ary (2010), qualitative research focused on understanding social phenomena from the perspective of the human participants in natural settings. So, descriptive qualitative method means to describe the result of observation with the help data search from existing sources. The technique of collecting is taken from the poem text, underlining the stanzas, lines, or words containing of imageries and revealing psychoanalytic aspects. The procedures of the analysis; firstly, the writer chooses Dover Beach poem. Then the writer reads that poem carefully and decides what subject that is interesting to be discussed. The writer chooses the imagery as one of the most interesting subjects in a poem to be discussed in this paper using psychoanalytic perspective. The next step is collecting the data related to this subject in some libraries providing references and information about the material that she needs. The last step is the writer analyzes those poems using the theory books related to the subject

\section{FINDING AND RESULT}

\section{Description of "Dover Beach" Poem}

Matthew Arnold is a type of writer who intends to social problem and instructs the reader on social issues. His poem, Dover Beach, talks about a social issue that is the fading of religion. The theme of the poem is the human misery because of their fading religion. The set of the poem is in Dover Beach - a town in southern England that connects the England channel on southern to north sea on northern. The poem was written in his honeymoon term in 1851 and was first published in 1867 in the collection New Poems (Arnold, 2004).

The poem starts with description of the nature, that the sea is calm that night, the tide is full, the moon lies fair. The poet uses sea as symbolism of religion. The phrase gleam and is gone and Glimmering and vast show the blinking of light that is the faith in religion which is sometimes strong and sometimes weak. Then the speaker asks his companion to view the nature through the window to feel the sweet night air. He mentions the moon as the land that is reflected on the sea's surface. The grating roar of pebbles portraits the clashing and disturbing sound of pebbles that is the violence. The next two lines express the conflict that causes sadness.

This poem tried to teach religion and social control that has to build as life foundation. The role of religion in defining and being affected by morality and social control is presented. Various aspects of religion affect moral behaviors and serve as social control mechanisms. Thus, religion is sometimes cast as immoral and deviant (Hoffmann, 2015). While, religion has an essential of human meaning in life. These findings suggest that meaning in life is a crucial element of religious coping and psychological well-being that is used by people as a part of their meaning system to cope with life's difficulties and challenges (Krok, 2015). Many writers express religious values in the form of poetry. They describe the journey of religious life in beautiful words. As in the poems of Taufik Ismail who want to touch the reader's feelings about the representation of religious values to shape the nation's character (Septia, Marni, \& Armet, 2019). In addition, Emily Dickinson's poems have also presented the themes and meanings of human life related to their God which are symbolized and illustrated by various things, and personally considered in the reflection of Emily Dickinsons' life (Sulaiman, 2017).

The poet makes his reference to "Sophocles a famous Greek dramatist long ago, of the $5^{\text {th }}$ Century B.C" in a passage of his play "Antigone" in this play the poet refers to the same sadness on the movement wave of the Aegaean - arm of the Mediterranean's sea between Greece and Turkey. The tide of misfortune causes the human misery. Then the poet expresses the feelings that he understands from the sound of the sea, the same thought as Sophocles had, this creates a relation between the eras.

In the beginning of the next stanza the poet uses phrase sea of faith to express faith in religion that once people had, all people around the world believe in God. But then he speaks about the present era where the religious is withdrawing itself from the world creating an effect of sorrow and melancholy. The sorrow and the melancholy retreat human to the misery in facing the drear and gloomy world without religion.

The poet/speaker calls for his love and he talks about the land as a land of dreams, that is so various, so beautiful and so new, then he talks about the darkling land that has no love, no joy, and no light. This is a dangerous thing that makes conflict and confusion for people in their struggle for life. He ends the poem and the stanza with an allusion about ignorant armies clash by night which is referring to the Greek battle.

\section{Imagery of "Dover Beach" Poem}

In this analysis the writer will analyze the poem line by line to make it easier in understanding the imagery that appears in the poem. The imagery that is found in Dover Beach poem is as follow: 


\section{A. Visual Imagery}

In the first stanza of Dover Beach poem, the imagery which is seen clearly is Visual Imagery or imagery which related to sight as follow:

The sea is calm tonight.
The tide is full, the moon lies fair
Upon the straits - on the French
coast the light
Gleams and is gone; the cliffs of
England stand,
Glimmering and vast, out in
the tranquil bay.

(line 1)

(line 2)

(line 3)

(line 4)

(line 5)

The sea is calm is visual imagery that invites the readers to imagine the sea which is calm as they can see it such pretending they are at the scene, they are standing by the seashore and watching the gentle waves splashing the sandy shores of the Straits. There is a weak breeze that blows gently and the sea looks calm for the night. The tide is full, the moon lies fair this line also gives the reader visual image of the tide which is full and the moon that looks bright as it shines its beams on the quiet sea. The light gleams and is gone ; the cliffs of England stand, Glimmering and vast these lines will trigger the reader's mind to imagine about the light that can be seen and then it is gone when the dark is over. From the French Coast across the England Channel to the high sea cliffs of England, the light shines pleasantly and softly, and gets weakened towards the tranquil bay of England. So, Visual Imagery helps the readers in imagining visually the thing that they read in the poem.

Visual Imagery in Dover Beach poem also can be found in the $7^{\text {th }}$ and $8^{\text {th }}$ lines as follow:

Only, from the long line of spray

(line 7)

Where the sea meets the moon-

blanched land,

(line 8)

The phrases long line of spray and the sea meets the moon-blanched land are Visual Imageries that invite the reader to imagine the long line of spray where the sea meets the moon and the land. The image of the moon touches the sea's surface is the beautiful scenery in the distance of unlimited sea. The scene of poem will come as a visualization when the speaker/poet and his companion watch the seashore from the height of their cabin, where they can view the waters of the sea that only touch the moonlit blended Colour of the sands.

Then in the $1^{\text {st }}$ line of the $3^{\text {rd }}$ stanza also appears Visual Imagery - image of sight. It is as follow:

The Sea of Faith

(line 21)

Was once, too, at the full, and round earth's shore

(line 22)

Lay like the folds of a bright girdle furled.

(line 23)

When reader reads the second line and the third line in stanza above that are in phrases at the full, and round earth's shore and Lay like the folds of a bright girdle furled they are invited to imagine the sea which is full, and rounds earth's shore. The sea lays like the fold of bright girdle furled. The sea was once a beholder of faith with its vastness that touches all the shores of the earth around the globe, lays folded like a bright girdle cord worn around the waist and rolled up fastened and firm. It is clear by those phrases the reader is asked to imagine something that can be seen and it is called Visual Imagery.

In the last stanza also contains Visual Imagery - image of sight. It can be found in the line as follow:

Ah, love, let us be true

(line 29)

To one another! For the world, which seems

To lie before us like a land of dreams,

(line 30)

So various, so beautiful, so new,

(line 31)

(line 32)

The phrase the world, which seems to lie before us is Visual Imagery. The image that invites the reader to see it in their imagination is the sight of the world that seems to lie down like a land of dreams, that land of dreams is so various, beautiful, and new the same as the world where people live in before. It is the land where people can find everything there while in the reality the present world they live in is opposite of it. So the image will be just the imagination of the beautiful world they want to be and they wish for. The scene that occurs from those lines of poem is the scene when the speaker/poet asks his companion to be honest with each other for the world they live in.

\section{B. Olfactory Imagery}

The Olfactory Imagery (image of smell) in the poem is found in the line below:

Come to the window, sweet is the night air!

(line 6)

From that line the word sweet is Olfactory Imagery that invites the reader to imagine the smell of the sweet air in that night as they experience it by themselves. The sweet smell of a night air can be calming and relaxing as the night pass by. The scene in the poem could be the speaker/poet tells his wife to come to the window of his cabin to enjoy the sweet aroma of the night air and also to enjoy their moment of togetherness at night. 


\section{Auditory Imagery}

There is Auditory Imagery (image of sound) that is used in the poem to stimulate readers' sense of hearing mentally. It is found in the line as follow:

\section{Listen! You hear the grating roar}

(line 9)

The phrase grating roar is Auditory Imagery. It invites the reader to hear the grating roar of the pebbles which is sometimes annoying when people want to go to the sea to seek the peace and to calm themselves down, but sometimes for some other people the sound can make them enjoy because the sound is the real nature sound in the sea which is the sound of the pebbles that is drew by the waves. From that line can be imagined the scene when the speaker/poet hears the roar of the sea as pebbles crashed away by the waves.

In the $2^{\text {nd }}$ stanza is also found Auditory Imagery - Image of sound as follow:

\section{Sophocles long ago}

(line 15)

Heard it on the Aegean, and

it brought

Into his mind the turbid ebb and

flow

Find also in the sound a thought,

Hearing it by this distant

northern sea.

(line 19)

(line 20)

When reader reads the word heard, it will lead them to imagine something that can be heard like kind of sound, in this context, heard means the poet heard or read the story on the Aegean written by Sophocles, the story about the misery of human's life. Then the phrase the sound a thought is also Auditory Imagery but in this context the sound is heard mentally that people have unconscious area in their mind, they sometimes talk to themselves. This means people can hear, talk, and debate to themselves unconsciously. This human's misery is told by Sophocles that he mentions about misery and sadness described by the northern sea.

Then the next line of the next stanza contains Auditory Imagery - image of sound as follow:

But now I only hear

(line 24)

Its melancholy, long,

withdrawing roar,

(line 25)

Retreating, to the breath

Of the night wind, down the vast

edges drear

And naked shingles of the world. (line 28)

The Auditory Imagery that is found from the stanza above comes from the word roar. When the reader reads it, the image that will appear from this word is the image of roar of something, in this context the roar is coming from the sound of night wind which is buzzing down to the vast edges drear and naked shingles of the world. It is the imagination of the sound which is heard so melancholy and long. It seems the wind is sad and in agony. The reader is invited to imagine hearing the sound of the waves in the sea which are retreating at the breath of the night wind that blows down the dull and gloomy edges of the bare shingles of the world.

\section{Kinesthetic Imagery}

Kinesthetic Imagery (image of motion) in the poem appears in the last 5 lines of the $1^{\text {st }}$ stanza as follow:

Of pebbles which the waves

draw back, and fling, (line 10)

At their return, up the high strand, (line 11) Begin, and cease, and then again

begin,

(line 12)

With tremulous cadence slow, and bring

(line 13)

The eternal note of sadness in.

(line 14)

The Phrases waves draw back, and fling, up the high strand, begin, and cease and tremulous cadence slow are Kinesthetic Imagery. It invites the readers to imagine the movement of the waves which draw back and fling the pebbles. When they return it is up to the high and then leave the pebbles stranded. It ceases for a while then begins again, and again. There will be the image of the pebbles crashed away by the blowing waves to the see's shore and then crashed back suddenly by the withdrawing waves. This phenomenon continues throughout the night with a slow trembling note and presence of melancholy is felt.

\section{E. Organic Imagery}

Organic Imagery (image of an internal sensation) is found in the line as follow:

Of human misery; we

(line 18)

The phrase human misery is Organic Imagery. The word misery can lead the reader to imagine something that hurts their feeling, such as sadness, mourn, unhappiness, sorrow, etc. The reader is invited to feel the sense of hurting that is described by the speaker/poet as well. It is the imagination of how painful the feeling of sadness is because of the misery which people have.

Then in the last 5 lines of the last stanza also contain of Organic Imagery - image of internal sensation as follow:

Hath really neither joy, nor love, nor light, (line 33) 
help for pain;

(line 34)

And we are here as on a darkling

plain

Swept with confused alarms of

struggle and flight,

Where ignorant armies clash

by night.

(line 36)

(line 37)

The words joy, love, peace, and pain are Organic Imageries. They are the images of some internal sensations that invite the reader to sense and feel it the same as the feeling of the speaker/poet had in that time. The land of dream does not have joy, love, peace, pain and spiritual light as it did before. There is no more certainty for help in times of trouble and peace. It is the same as in the world where people live in today. All the mortals live in this world in a dark state of mind and the struggle to survive is no less different from ignorant armies that fight throughout the night.

It can be concluded that imagery is as the imagination form of author's expression in poetry. Imagination in contemporary poetry moves more towards imaging rather than poetic imagination. In other words, imagination shows greater affinity to imaging in contemporary poetry (Zalipour, 2011). Based on theoretical studies, it can be seen that imagery studies are drawn in three parts, including (i) a parable study cannot rule out the study of figures of speech (i.e figures of speech related to word choice and meaning manipulation), even if they are not specifically dealt with, (ii) the study of parables, as an inevitable element of poetry, has attracted the interest of literary theorists for centuries, but their differing views about literature or their approach to his studies, (iii) analytic methods as described above will direct our attention on the most repetitive (and hence the most important) images in poetic works (LLORENS, 2003)

\section{Psychoanalytic Aspects of "Dover Beach" Poem}

In this analysis the writer will also analyze the poem line by line to describe the psychoanalytic aspects revealed in this poem.

\section{A. Unconscious}

The sea is calm tonight.

(line 1)

The tide is full, the moon

lies fair

(line 2)

Upon the straits - on

the French coast the light

(line 3)

Gleams and is gone;

the cliffs of England stand,

(line 4)

Glimmering and vast, out in the tranquil bay.

(line 5)

Come to the window, sweet is the night air!
In this stanza the poet describes the pleasant time he has by spending at the beach, he enjoys the calm situation offered by the sea and the sweet of the night air. He asks his beloved wife to come to the window to enjoy the moment. This is the conscious mind where people aware of their happy moment and enjoy it.

\begin{tabular}{|c|c|}
\hline$\underline{\text { ar }}$ & \\
\hline & \\
\hline $\begin{array}{l}\text { eir return, up the high strand, } \\
\text {, and cease, and then again } \\
\text { tremulous cadence slow, and }\end{array}$ & \\
\hline The eternal note of sadness & 14 \\
\hline
\end{tabular}

Then through this stanza the poet describes about the sadness he feels and wants to be forgotten, yet it keeps appearing though he is in the happy and pleased moment. The unconscious mind where unhappiness and disappointment are stored somehow will appear and control the feeling. The disappointment of the poet might be related to the situation when the poem is created in which the society of the era when the poet lives is really frustrating him. The time when he enjoys the calm situation at his room nears the beach is heard the grating roar of pebbles which the waves draw back, and fling which is annoying for him. It is like his feeling about the sadness and disappointment, he tries to repress toward the situation where he lives, the situation when people colonized by the machines. The Victorian era when the poet lived was the era when the industrial was growth fast and gave the negative impact for the generation. He criticized the society in England when people placed their faith in material things and individual satisfaction in which the faith was getting fade as the modernity took place.

\section{B. The Id, the Ego, and the Superego}

The Sea of Faith

(line 21)

Was once, too, at the full, and round earth's shore

(line 22)

Lay like the folds of a bright girdle furled.

But now I only hear

(line 23)

Its melancholy, long,

withdrawing roar,

(line 24)

Retreating, to the breath

(line 25)

Of the night wind, down the vast

edges drear

(line 26)

(line 27)

And naked shingles of the world. (line 28) 
Instead of enjoying his intimate and pleased moment with his wife the poet continues to complain and reveal his true feeling of pessimistic toward the world he lives in. The way people lived their live in that era really frustrated him. The super ego of the poet influences the way he perceives the world. The background of the poet as an educated man who lives in a religious family influences him to believe that the world would be better if people stayed strong to keep their faith and belief. As it used to be when the faith was like the sea which once rounded earth's shore and laid like the folds of a bright girdle furled, the way belt worn round the waist tight so did the faith. It was not the way to live in by the machinery expansion wrapped up human life as it happened in the era of poet's life. This is the way of the ego ideal which makes the judgment of how the ideal world according to him.

$\begin{array}{ll}\begin{array}{l}\text { Ah, love, let us be true } \\ \text { To one another! For the world, } \\ \text { which seems }\end{array} & \text { (line 29) } \\ \begin{array}{l}\text { To lie before us like a land of } \\ \text { dreams, }\end{array} & \text { (line 30) } \\ \begin{array}{l}\text { So various, so beautiful, so new, } \\ \text { Hath really neither joy, nor love, }\end{array} & \text { (line 32) } \\ \begin{array}{l}\text { nor light, } \\ \text { Nor certitude, nor peace, nor }\end{array} & \text { (line 33) } \\ \begin{array}{l}\text { Help for pain; } \\ \begin{array}{l}\text { And we are here as on a darkling } \\ \text { plain }\end{array}\end{array} \\ \begin{array}{l}\text { Swept with confused alarms of } \\ \text { struggle and flight, }\end{array} \\ \begin{array}{l}\text { Where ignorant armies clash } \\ \text { by night. }\end{array} & \text { (line 36) } \\ \end{array}$

In this stanza the poet seems to be back to real moment where he is, the moment when there is a companion (a wife) beside him who listens and at the same time needs him to be aware of her presence. Despite of his frustration there is a hope of happiness which can be gain through love. It is by honest and true to each other. The power of love which most people believe can help and cure wound in the heart and fade the anxiety and pessimistic toward the life.

The world where the sea is calm, the moon is fair, and the air is sweet is like the land of dream which is so various, so beautiful, and so new. The same as the new world where the machinery takes shift as the industrial revolution comes giving the view of the various worlds which are beautiful. The superego of the poet appears again through this stanza, in which, he thinks that even the world will become beautiful because of the modernity and the industrial that can provide every need of people, there will be no neither joy, nor love, nor light, nor certitude, nor peace, nor help for pain if the faith fades. The poet presumes that people will be confused alarms of struggle and flight, where ignorant armies clash by night without religion and then it will lead them to the foolishness and ignorance that can cause and trigger the human's misery like it is heard from Sophocles long ago.

In Freud' theory concluded that there are three layers of personality, namely the id, the ego, and the superego. Utomo's research (2015) stated that the id and the superego in the poems are represented by the speaker of the poems themselves, which is the horse rider in Stopping by Woods on a Snowy Evening, and the Christian in Poor soul. Second, the conflict between the id and superego in each poem is reflected in one event and in one character. In both of the poems, the superego becomes the winner in the conflicts against the id. Third, there are some values of character which are reflected in the poems, namely discipline, curiosity, friendly/ communicative, and responsibility in Stopping by Woods on a Snowy Evening, while in Poor Soul are religious, friendly/communicative, social care, and responsibility.

\section{CONCLUSION}

Dover Beach poem is the poem which has the most various imageries. It contains Visual Imagery (image of sight), Olfactory Imagery (image of smell), Auditory Imagery (image of sound), Kinesthetic Imagery (image of motion), and Organic Imagery (image of an internal sensation). Those imageries will help the readers in understanding the poem more deeply because through those imageries the readers can unveil the real meaning contained on it as they imagine what the things that are described by the speaker/poet like it is real and really seen, felt, touched, heard, smelled and tasted by themselves. In Dover Beach poem is found some of psychoanalytic aspects such as unconscious and the id, ego, and superego which reveal the poet's feeling, depression, and anxiety when the poem was written. All those psychoanalytic aspects revealed in Dover Beach poem will help the readers to gather more information about the poems and to know the relationship with its author. Most of Arnold's poems talks about the death. It is about his wish and fear of condition when he dies. The poet seems anxious to leave his youth, grow old, and bear the deathful illness which will cause his death. Even though he is a religious man who has his faith and belief, he still reveals his fear of death. This is humane for everyone to fear the death.

A poem as a literary work contains the elements of art that are always enganging to be discussed and analyzed as the work of scientific writing. The poem has never changed for years. It always has special place for people to be learned. People have never gotten bored to discuss and 
analyze a poem. There is always something new which comes up when they are working on it. It can be different for someone whom works on it and for another one. At the end the result is always interesting and surprising that it can bring different meaning for each people

\section{REFERENCES}

Arnold, M. (2004). Classic Poetry Series : Matthew Arnold Poems.

Ary, D. (2010). Introduction to Research in Education. Cengage Learning.

Barry, P. (2002). Beginning Theory; An Introduction to Literary and Cultural Theory, Second Edition. United Kingdom: Manchester University Press.

Dietsch, B. M. (2003). Reasoning and Writing Well: a Rhetoric, Research Guide, Reader, and Handbook. New York: The McGraw-Hill Companies, Inc.

DiYanni, R. (2004). Literature: Approaches to Fiction, Poetry, and Drama. New York: The McGraw-Hill Companies, Inc.

Eagleton, T. (2008). Literary Theory; An Introduction. Unites States: Blackwell Publishers Ltd.

Hoffmann, J. P. (2015). Religion: Morality and Social Control. International Encyclopedia of the Social \& Behavioral Sciences, 333-337. https://doi.org/10.1016/B978-0-08-0970868.84036-2

Krok, D. (2015). The Role of Meaning in Life Within the Relations of Religious Coping and Psychological Well-Being. Journal of Religion and Health, 54(6), 2292-2308. https://doi.org/10.1007/s10943-014-9983-3

LLORENS, D. (2003). The Analysis of Poetic Imagery. $\quad$ Retrieved from http://repositori.uji.es/xmlui/bitstream/handle/ 10234/79167/forum_2003_3.pdf?sequence=1

Perrine, L., \& ARP, T. R. (1992). Sound and Sense: An introduction to Poem, Eight Edition. New York: Harcourt Brace Jovanovich College Publishers.

Pharr, D., \& Buscemi, S. V. (2005). Writing Today, Brief Edition. New York: McGraw Hill.
Septia, E., Marni, S., \& Armet, A. (2019). REPRESENTASI NILAI RELIGI DAN KEPENGARANGAN PUISI-PUISI KARYA TAUFIK ISMAIL. Jurnal POETIKA, 7(1), 32-50.

https://doi.org/10.22146/POETIKA.43493

Stanford, J. A. (2006). Responding to Literature: Stories, Poems, Plays, and Essays. New York: McGraw Hill, an imprint of The McGraw-Hill Companies, Inc.

Sulaiman, M. (2017). IMAGERY ANALYSIS ON EMILY DICKINSONS POETRY. English Community Journal, 1(1), 33. https://doi.org/10.32502/ecj.v1i1.649

Utomo, D. (2015). A STUDY OF CONFLICT BETWEEN THE ID AND SUPEREGO ASREFLECTED IN STOPPING BY WOODS ON A SNOWY EVENING BYROBERT FROST AND IN POOR SOUL BY WILLIAM SHAKESPEAREAND ITS CONTRIBUTION TO CHARACTER EDUCATION INTEACHING READING OF SMA. Retrieved from https://eprints.uns.ac.id/17694/

Zalipour, A. (2011). From Poetic Imagination to Imaging: Contemporary Notions of Poetic Imaginationin Poetry. Rupkatha Journal on Interdisciplinary Studies in Humanities, 3(4). 